\title{
Regulation of the gp80 and gp130 Subunits of the IL-6 Receptor by Sex Steroids in the Murine Bone Marrow
}

\author{
Song-Chang Lin, Tomoo Yamate, Yasuto Taguchi, Victoria Z.C. Borba, Giuseppe Girasole, Charles A. O'Brien, \\ Teresita Bellido, Etsuko Abe, and Stavros C. Manolagas \\ Division of Endocrinology, University of Arkansas for Medical Sciences Center for Osteoporosis and Metabolic Bone Diseases; and \\ Geriatric Research, Education and Clinical Center, Veterans Administration Medical Center, Little Rock, Arkansas 72205
}

\begin{abstract}
Both estrogen and androgen exert their antiosteoporotic effects, at least in part, by inhibiting IL-6 production, thereby suppressing osteoclastogenesis. Several observations, however, suggest that besides increased IL-6 production, sensitivity of the osteoclastogenic process to this cytokine is altered after ovariectomy. Based on this and evidence that the ligand-binding subunit of the IL-6 receptor (gp80) is a limiting factor for the actions of IL-6 on bone, we hypothesized that sex steroids regulate expression of the IL-6 receptor as well. We report that $17 \beta$-estradiol or dihydrotestosterone in vitro decreased the abundance of the gp80 mRNA as well as the mRNA of the signal-transducing subunit of the IL-6 receptor (gp130) in cells of the bone marrow stromal/osteoblastic lineage, and also decreased gp130 protein levels. These effects did not require new protein synthesis. In contrast to sex steroids, parathyroid hormone stimulated gp130 expression; this effect was opposed by sex steroids. Consistent with these findings, ovariectomy in mice caused an increase in expression of gp80, gp130, and IL-6 mRNAs in ex vivo bone marrow cell cultures as determined by quantitative reverse transcription (RT)-PCR, and confirmed on an individual cell basis using in situ RT-PCR. The demonstration of increased expression of the IL-6 receptor after loss of sex steroids provides an explanation for why IL-6 is important for skeletal homeostasis in the sex steroid-deficient, but not replete, state. (J. Clin. Invest. 1997. 100:1980-1990.) Key words: osteoporosis - cytokines - estrogen • androgen • cytokine receptors
\end{abstract}

\section{Introduction}

Evidence accumulated during the last five years has implicated IL-6 in the pathophysiology of several diseases caused by increased osteoclastic bone resorption, including osteoporosis of estrogen or androgen deficiency (1-4), hyperparathyroidism

Song-Chang Lin and Tomoo Yamate should both be considered as first authors in this paper. Giuseppe Girasole's current affiliation is Universita de Parma, Istituto di Clinica Medica Generale, Parma, Italy.

Address correspondence to Stavros C. Manolagas, M.D., Ph.D., Director, Division of Endocrinology and Metabolism, University of Arkansas for Medical Sciences, 4301 West Markham, Mail Slot 587, Little Rock, AR 72205. Phone: 501-686-5130; FAX: 501-686-8148; E-mail:manolagass@exchange.uams.edu

Received for publication 30 December 1996 and accepted in revised form 26 August 1997.

The Journal of Clinical Investigation

Volume 100, Number 8, October 1997, 1980-1990

http://www.jci.org
$(5,6)$, Paget's disease (7), multiple myeloma (8), rheumatoid arthritis $(9,10)$, Gorham-Stout disease (11), hyperthyroidism $(12,13)$, McCune-Albright syndrome (14), and renal osteodystrophy (15).

Production of IL- 6 by cells of the stromal/osteoblastic lineage is inhibited in vitro by both estrogen and androgen $(3,16)$ through receptor-mediated actions on the transcriptional activity of the IL-6 gene promoter (3, 17-19). Conversely, estrogen loss results in increased IL- 6 production by ex vivo bone marrow cell cultures (20), and increased IL-6 production follows withdrawal of estradiol from primary cultures of calvarial cells (21). Consistent with the in vitro data, increased IL-6 levels have been detected in bone marrow supernatants from ovariectomized compared with sham-operated mice (22), as well as in the serum of rats and in serum from postmenopausal compared with premenopausal women $(13,23)$. In addition, estrogen was found to suppress endotoxin-stimulated IL-6 production in vivo (24). In contrast to these studies, however, others have not found differences in serum IL-6 levels when comparing pre- and postmenopausal women (25), and there was no difference in IL-6 levels in bone marrow aspirates from postmenopausal women with or without hormone replacement therapy (26). In direct support of the contention that IL-6 is responsible for increased bone resorption that ensues after loss of sex steroids, injections of an IL-6-neutralizing antibody to gonadectomized female or male mice prevent increases in osteoclastogenesis in the bone marrow and increases in numbers of osteoclasts in sections of trabecular bone, but has no effect on osteoclast development in sex steroid-sufficient animals (2, 3). Furthermore, unlike wild-type controls, IL-6 knockout mice do not exhibit the cellular changes in the marrow and trabecular bone sections, and are protected from loss of trabecular bone after loss of sex steroids $(3,27)$.

IL-6 exerts its effects on target cells via a bipartite cell surface receptor. Binding of the ligand to the $\alpha$-subunit of the IL- 6 receptor, a glycoprotein of $80 \mathrm{kD}$ (gp80), causes homodimerization of the signal-transducing $\beta$-subunit (gp130). Ligandinduced dimerization of the $\beta$-subunit initiates intracellular signaling by activating members of a family of receptor-associated tyrosine kinases known as the Janus kinases, which in turn phosphorylate several proteins, including the $\beta$-subunit of the receptor complex, the kinases, and a series of cytoplasmic proteins termed STATs (signal transducers and activators of transcription). ${ }^{1}$ STAT phosphorylation causes the formation of protein complexes that migrate to the nucleus and initiate gene transcription (28-31). The $\alpha$-subunit of the IL-6 receptor also occurs in soluble form. While the soluble extracellular

1. Abbreviations used in this paper: AP, alkaline phosphatase; DEPC, diethyl pyrocarbonate; DHT, dihydrotestosterone; OVX, ovariectomized; RT, reverse transcription; STAT, signal transducers and activators of transcription. 
domains of most receptors function as antagonists, however, the soluble IL-6 receptor (sIL-6R) functions agonistically by binding its cognate cytokine and then interacting with the signal-transducing component of the receptor on the cell surface $(28,29)$.

Even though IL-6 is implicated as a pathogenetic factor in several disease states of increased bone resorption, it is seemingly unimportant for osteoclastogenesis under normal conditions $(2,3,32)$, and administration of IL-6 to mice does not increase osteoclastogenesis (33). Thus, administration of a neutralizing IL-6 antibody to estrogen-sufficient mice or to ex vivo cultures of bone marrow cells from sex steroid-sufficient mice has no effect on osteoclastogenesis. Also, osteoclastogenesis is unaffected in IL-6 deficient mice $(2,3,27)$, indicating that the osteoclastogenic process in the estrogen-sufficient state is insensitive to IL-6. Moreover, expression of the $\alpha$-subunit of the IL-6 receptor in bone is a limiting factor (34), and the osteoclastogenic effects of IL-6 in bone marrow cultures can only be demonstrated when exogenous sIL-6R is provided (35). Based on these pieces of evidence, we have reasoned that sex steroids not only suppress the expression of IL-6, but also suppress expression of the IL- 6 receptor. The results of the experiments presented in this paper indicate that sex steroids act on stro$\mathrm{mal} /$ osteoblastic cell models to decrease the expression of the genes encoding the ligand-binding as well as the signal-transducing subunits of the IL-6 receptor, and that ovariectomy in mice causes an increase in the expression of these two genes, as well as the IL-6 gene, in cells of the bone marrow of mice.

\section{Methods}

Materials. 17ß-estradiol $\left(\mathrm{E}_{2}\right)$, dihydrotestosterone (DHT), cycloheximide, diethyl pyrocarbonate (DEPC), McCoy's 5A medium, FBS, and anti- $\beta$-actin monoclonal antibody were purchased from Sigma Chemical Co. (St. Louis, MO). $1,25(\mathrm{OH})_{2} \mathrm{D}_{3}$ was generously provided by Dr. Milan Uskokovic (Hoffman-La Roche, Nutley, NJ). Synthetic bovine PTH (1-34) was purchased from Peninsula Laboratories, Inc. (Belmont, CA), and human recombinant IL-11, IL-1 $\beta$, and murine TNF- $\alpha$ were purchased from Genzyme Corp. (Cambridge, MA). Murine IL-6, gp80, and gp130 plasmids were kindly provided by Dr. Tadamitsu Kishimoto of Osaka University, Japan. Dulbecco's Modified Eagle Medium and $\alpha$-MEM were obtained from GIBCO BRL (Gaithersburg, MD). [ $\left.\alpha^{32} \mathrm{P}\right] \mathrm{dCTP}(3,000 \mathrm{Ci} / \mathrm{mmol})$ was from Amersham Corp. (Arlington Heights, IL). LIF and rabbit anti-human gp130 polyclonal antiserum were purchased from Upstate Biotechnology, Inc. (Lake Placid, NY). Goat anti-mouse IgG + IgM conjugated with horseradish peroxidase was purchased from Caltag Laboratories (San Francisco, CA). Polyclonal goat anti-rabbit IgG-HRP antibody and polyclonal anti-murine gp130 were from Santa Cruz Biotechnology Inc. (Santa Cruz, CA). Protein A-Sepharose was bought from Pharmacia LKB Biotechnology, Inc. (Piscataway, NJ), and enhanced chemiluminescence reagents were bought from DuPont-NEN (Boston, MA).

Cell lines and primary bone marrow cell cultures. The +/+LDA.11 stromal cell line was established from hematopoietically inactive long-term murine bone marrow cultures (16), and was cultured in McCoy's 5A medium with $10 \%$ FBS. The murine calvaria-derived osteoblast-like cell line MC3T3-E1 (36) was cultured in phenol redfree MEM supplemented with $10 \%$ FBS. The 2107 cell line is a spontaneously transformed cell line derived from newborn calvarial cells obtained from SAMP6 mice (kindly provided by Dr. T. Sato, Daiichi Pharmaceutical Co., Tokyo, Japan), and was cultured in phenol red-free $\alpha$-MEM supplemented with $10 \%$ FBS. MG-63 and SaOs-2 human osteoblast-like osteosarcoma cells were maintained in phenol red-free MEM containing $10 \%$ FBS $(37,38)$. Primary cultures of mu- rine bone marrow cells were established from aspirates from the femur and tibia of control, sham-operated or ovariectomized (OVX) 60-d-old Swiss Webster mice as previously described (2). All procedures were performed in accordance with the National Institutes of Health Guidelines for Care and Use of Laboratory Animals. Bone marrow cells were obtained $2 \mathrm{wk}$ after the operation, and were resuspended $\left(10^{6}\right.$ cells $\left./ \mathrm{ml}\right)$ in $\alpha$-MEM. Cells were seeded either in $75-\mathrm{cm}^{2}$ flasks or in 12-well plates with coverslips, and were maintained with $10^{-8} \mathrm{M} 1,25(\mathrm{OH})_{2} \mathrm{D}_{3}$ for $7 \mathrm{~d}$ with $10 \%$ FBS. $80 \%$ of the medium was replaced with fresh medium every $3 \mathrm{~d}$. All media contained penicillin $(100 \mathrm{U} / \mathrm{ml})$ and streptomycin $(100 \mu \mathrm{g} / \mathrm{ml})$. In the experiments examining the effect of sex steroids, PTH, or cytokines, the medium of semiconfluent cultures was changed to fresh medium containing $2 \%$ FBS, the agents were added, and the culture was continued for another $24 \mathrm{~h}$. For quantification of the IL-6 mRNA by in situ or quantitative reverse transcription (RT)-PCR, cells were stimulated with $0.3 \mathrm{nM}$ hIL-1 $\beta$ and $1 \mathrm{nM} \mathrm{mTNF} \alpha$ for $3 \mathrm{~h}$ before termination of the culture.

Northern blot analysis. Total RNA was isolated and analyzed essentially as previously described (34). Blots were hybridized separately with the radiolabeled cDNA specific for the murine IL-6R $\alpha$ (gp80), murine gp130, or the housekeeping gene Cho B, and analyzed using a PhosphorImager ${ }^{\mathrm{TM}}$ (Molecular Dynamics, Sunnyvale, CA).

Western blot analysis. Cells cultured in the absence or presence of steroids were lysed in buffer containing $20 \mathrm{mM}$ Hepes, $\mathrm{pH} 7.5,5$ $\mathrm{mM} \mathrm{KCl}, 5 \mathrm{mM} \mathrm{MgCl}, 10 \%$ glycerol, $0.5 \%$ Nonidet $\mathrm{P}-40,1 \mathrm{mM}$ sodium orthovanadate, $1 \mathrm{mM}$ PMSF, $5 \mu \mathrm{g} / \mathrm{ml}$ trypsin inhibitor, and $5 \mu \mathrm{g} / \mathrm{ml}$ protease inhibitors pepstatin, leupeptin, and aprotinin. Cell lysates were centrifuged at $500 \mathrm{~g}$ for $5 \mathrm{~min}$, and the resulting supernatants were collected and further centrifuged at $14,000 \mathrm{~g}$ for $10 \mathrm{~min}$. All procedures were performed on ice or at $4^{\circ} \mathrm{C}$. Protein concentration was determined by a protein assay (Bio-Rad Laboratories, Richmond, CA). $20 \mu \mathrm{g}$ of total protein were resolved in $6 \%$ polyacrylamide/SDS gels and electroblotted to polyvinylidene difluoride membranes. Membranes were blocked for $1 \mathrm{~h}$ at room temperature in 5\% nonfat dry milk in PBS containing $0.05 \%$ Tween 20 , and were subsequently incubated with the rabbit anti-human gp130 polyclonal antibody and a goat anti-rabbit IgG-HRP-conjugated polyclonal antibody. Blots were developed by ECL. After washing the gp130 antiserum by incubation in $0.2 \mathrm{M}$ glycine buffer ( $\mathrm{pH} 2.5$ ) and $0.05 \%$ Tween 20 at $80^{\circ} \mathrm{C}$ for $2 \mathrm{~h}$, membranes were reprobed with a mouse anti- $\beta$-actin monoclonal antibody and a secondary goat anti-mouse $\operatorname{Ig}(\mathrm{G}+\mathrm{M})$-HRPlinked antiserum. The intensity of the immunoreactive bands was quantified using a laser densitometer (Molecular Dynamics).

Competitive RT-PCR. Internal cRNA standards for IL-6, gp80, or gp130 were transcribed using T7, SP6, or T3 RNA polymerase according to the manufacturer's protocol. For templates we used the respective cDNA plasmids that were shortened by a 150-200-bp deletion from the authentic cDNA. For murine gp 80 and gp130 cDNAs, the authentic plasmids were cut with Bam HI/Hind III or Spe I/Eco RI to remove the respective fragments. The plasmids were then filled in by Klenow fragment and religated. For the IL- 6 cDNA, two Eco RI sites within the coding region were created and digested to make a shorter plasmid. The cRNAs were purified by fractionation on a $1 \%$ agarose gel to remove template DNA completely, and were stored until used in the presence of RNasin at $-20^{\circ} \mathrm{C}$. A constant concentration of total RNA ( $1 \mu \mathrm{g} /$ tube $)$ was mixed with nine serial dilutions $(1 / 1$ to $1 / 256$ ) of the internal cRNA standard. The cRNA standard and sample RNAs were mixed at this point so that the efficiency of the reverse transcriptase reaction would be the same for both templates. The first-strand cDNA was synthesized at $42^{\circ} \mathrm{C}$ for $1 \mathrm{~h}$ using random hexanucleotide primers ( $20 \mathrm{ng} / \mu \mathrm{l}$; Promega Corp., Madison, WI) and Superscript reverse transcriptase II ( $4 \mathrm{U} / \mu \mathrm{l}$; GIBCO BRL). The primers used for PCR were as follows: murine IL-6 (5'-primer, ATGAAGTTCCTCTCTGCAAGAGACT; 3'-primer, CACTAGGTTTGCCGAGTAGATCTC); murine gp80 (5'-primer, TGTCAACGCCATCTGTGAGTGG; 3'-primer, ACTTTCGTACTGATCCTCGTGG); murine gp130 (5'-primer, CAGCGTACACTGATGAAGGTGGGAAAGA; 3'-primer, GCTGACTGCAGTTCTGCTTGA); and glycer- 
aladehyde-3-phosphate dehydrogenase (GAPDH) (5'-primer, TGAAGGTCGGTGTGAACGGATTTGGC, and 3'-primer, CATGTAGGCCATGAGGTCCACCAC). These primer pairs should yield products of 615,643 , and $687 \mathrm{bp}$ for IL-6, gp80, and gp130, respectively. The PCR solution contained $0.4 \mu \mathrm{M}$ of each primer, $0.2 \mathrm{mM}$ dNTP (Pharmacia Fine Chemicals, Uppsala, Sweden), $1.55 \mathrm{mM} \mathrm{MgCl}$, $50 \mathrm{U} / \mathrm{ml}$ Taq polymerase, and $1 \times$ reaction buffer (Perkin-Elmer Corp., Norwalk, CT). The amplification was accomplished in a thermal cycler programmed as follows: $4 \mathrm{~min}$ at $94^{\circ} \mathrm{C}, 30$ cycles of $1 \mathrm{~min}$ at $94^{\circ} \mathrm{C}, 2 \mathrm{~min}$ at $65^{\circ} \mathrm{C}$, and $3 \mathrm{~min}$ at $72^{\circ} \mathrm{C}$. Finally, PCR products were loaded on a $2 \%$ agarose gel with ethidium bromide, and band intensity was quantified by photo image analyzer (FOTO/ANALYST-II; Fotodyne, Inc., New Berlin, WI). The ratio of band intensity of the sample to the internal standard was calculated in the four reactions that contained significant amounts of both sample and standard, and was plotted against the concentration of the internal cRNA standard in $\log / \log$ scale. Ratio $\log 0$ obtained from the regression line corresponds to the concentration of mRNA in the sample, as we have previously described (39).

In situ RT-PCR. Cells cultured on glass coverslips were washed with calcium-free PBS and treated with $0.1 \%$ DEPC. Subsequently, cells were fixed with $4 \%$ paraformaldehyde in $0.1 \mathrm{M}$ DEPC-treated phosphate buffer, $\mathrm{pH} 7.4$, for $3 \mathrm{~h}$ at $4^{\circ} \mathrm{C}$, washed with PBS three times, and soaked in $0.2 \mathrm{~N} \mathrm{HCl}$ for $20 \mathrm{~min}$ at room temperature. After this step, cells were sequentially washed with DEPC-treated water, $2 \times$ SSC, and PBS. At this stage, the cells were digested in 0.5 $\mu \mathrm{g} / \mathrm{ml}$ proteinase $\mathrm{K}$ in $10 \mathrm{mM}$ Tris buffer $(\mathrm{pH} 8.0)$ for $10 \mathrm{~min}$ at room temperature, fixed again in $4 \%$ paraformaldehyde for $60 \mathrm{~min}$ at $4^{\circ} \mathrm{C}$, washed with PBS three times, and dehydrated sequentially with 70 , 80,90 , and $100 \%$ ethanol. To remove genomic DNA or mRNA, cells were treated with RNase-free DNase I $(1,500 \mathrm{U} / \mathrm{ml})$ or DNase-free $\mathrm{RNase}(15 \mathrm{U} / \mathrm{ml})$ for $3 \mathrm{~h}$ at $37^{\circ} \mathrm{C}$. The first-strand cDNA was then synthesized in $1 \mathrm{mM}$ dNTP and $10 \mathrm{mM}$ DTT solutions containing $0.4 \mu \mathrm{M}$ of a gene-specific antisense ( $3^{\prime}$ end) primer and $4 \mathrm{U} / \mu \mathrm{l}$ Superscript reverse transcriptase II (Gibco-BRL) during a 60-min incubation at $42^{\circ} \mathrm{C}$. After washing with DEPC-treated water, the cDNA was ampli-

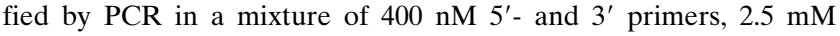
$\mathrm{MgCl}_{2}, 200 \mu \mathrm{M}$ dNTP, $10 \mu \mathrm{M}$ DIG-11-dUTP, and $0.1 \mathrm{U} / \mu \mathrm{l}$ Taq DNA polymerase using the GeneAmp In Situ PCR System $1000^{\mathrm{TM}}$ (PerkinElmer Corp.). The temperature profile for the PCR was programmed as follows: 4-min soak at $94^{\circ} \mathrm{C}, 10-50$ cycles of $94^{\circ} \mathrm{C}$ for $1 \mathrm{~min}, 65^{\circ} \mathrm{C}$ for $2 \mathrm{~min}$, and $72^{\circ} \mathrm{C}$ for $3 \mathrm{~min}$. Incorporated DIG-11-dUTP in the amplified PCR products was detected by AP-conjugated antidigoxigenin antibody, and was visualized with NBT and BCIP (DIG nucleic acid detection kit; Boehringer-Mannheim, Mannheim, Germany) after soaking in $1 \%$ blocking reagent for $30 \mathrm{~min}$ at room temperature. The mRNAs of interest were amplified using the same primers as those described in the competitive RT-PCR section above. Cells expressing the mRNAs stained dark purple. The mRNA abundance was determined in the entire area of each of at least 300 cells in randomly selected fields by measuring color intensity with an image analyzer (SAMBA 4000 Image Analysis System; International, Inc., Chantilly, VA). In each experiment, background staining (i.e., zero color intensity) was determined using samples prepared in the absence of reverse transcriptase. To determine the size distribution of the gp130 PCR product generated during in situ RT-PCR, $\left[{ }^{32} \mathrm{P}\right] \mathrm{dCTP}$ was included in the amplification reaction, and the radiolabeled DNA was extracted from the coverslips by digestion with proteinase $\mathrm{K}(100 \mu \mathrm{g} / \mathrm{ml})$ at $55^{\circ} \mathrm{C}$ for $2 \mathrm{~h}$ followed by extraction with phenol/chloroform and ethanol precipitation. The extracted DNA was resolved on a $3 \%$ agarose gel and transferred by capillary action to a Hybond $\mathrm{N}+$ membrane, that was exposed to a PhosphorImager screen (Molecular Dynamics, Sunnyvale, CA).

Statistics. Data are expressed as the means \pm SE from four replicate cultures per experiment and a minimum of three experiments for each experimental condition. Differences between groups were analyzed by ANOVA. Bonferroni's test was used to estimate the level of significance of differences between means.

\section{Results}

Results of a representative experiment examining the effects of sex steroids on the steady-state levels of the gp80 and gp130 mRNAs in $+/+$ LDA11 cells are illustrated in Fig. $1 A$. In this and subsequent experiments, two species of gp130 transcripts, with approximate sizes of 7 and $10 \mathrm{~kb}$, were seen, as it has been reported previously (40). The abundance of either the gp 80 or gp130 transcripts was decreased in cells treated with $10 \mathrm{nM} \mathrm{E}$ or $10 \mathrm{nM}$ DHT. This effect was apparent on both transcripts of gp130. Nonetheless, the magnitude of the effects of the sex steroids varied considerably in different experiments $(n=8)$. gp80 inhibition by $\mathrm{E}_{2}$ and DHT had a range between 9 and $67 \%$ and 21 and 59\%, respectively, and gp130 (both transcripts) inhibition ranged between 11 and $62 \%$ and 7 and $86 \%$. This variability may reflect the possibility that the effects of sex steroids on gp80 and gp130 are exerted in vivo on very early progenitors that are not represented well by the cell lines available for in vitro experimentation (Jilka et al., manuscript). The inhibitory effects of $\mathrm{E}_{2}$ and DHT on gp130 mRNA expression, however, were reproduced using the human osteoblastlike osteosarcoma cell line MG-63 $(n=2$, mean inhibition $28 \%$ for $\mathrm{E}_{2}$, and $41 \%$ for DHT; data not shown).

To ascertain whether the effects of sex steroids on gp130 mRNA were accompanied by corresponding changes in protein expression, the effect of $\mathrm{E}_{2}$ or DHT on gp130 protein was

\section{A. Northern Blot}
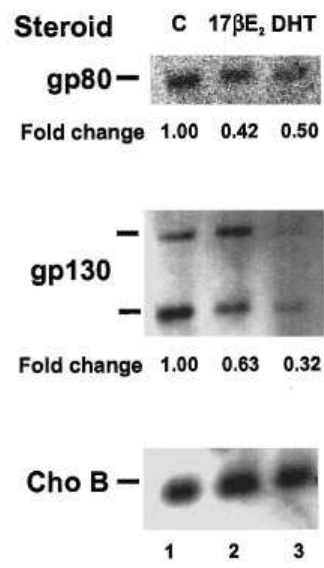

\section{B. Western Blot}

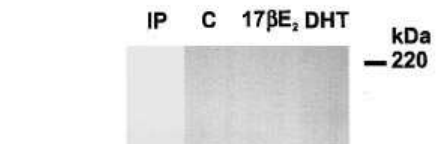

gp130

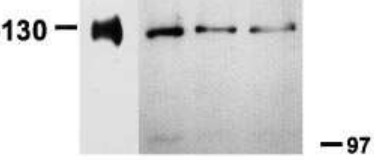

Fold change $\quad \begin{array}{llll}1.00 & 0.59 & 0.52\end{array}$

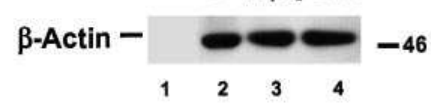

Figure 1. Sex steroids inhibit expression of gp 80 and gp130 mRNAs in murine bone marrow-derived stromal cells. +/+LDA11 murine bone marrow-derived stromal cells were cultured for $24 \mathrm{~h}$ in the absence $(C)$ or in the presence of $10^{-8} \mathrm{M} 17 \beta$-estradiol $\left(17 \beta \mathrm{E}_{2}\right)$, or $10^{-8} \mathrm{M}$ DHT. (A) Steady state levels of gp80, gp130, and ChoB mRNAs were determined by Northern blot using $5 \mu \mathrm{g}$ poly $\mathrm{A}^{+} \mathrm{RNA}$. The ratios of the intensity of the gp 80 or gp130 bands over the intensity of the $\mathrm{ChoB}$ band were determined by PhosphorImager, and were expressed as fold change relative to untreated controls $(C)$, designated as 1.0. Similar results were reproduced in four additional experiments. (B) gp130 protein levels were determined by Western blot analysis using an anti-gp130 antibody. The ratios of the intensity of the gp130 band over the $\beta$-actin band were determined by laser densitometry, and were expressed as fold changes relative to control, which was designated as 1 . A portion of cellular lysate from control cells was immunoprecipitated using anti-gp130 antibody bound to protein A Sepharose, and fractionated in the same gel (IP). 

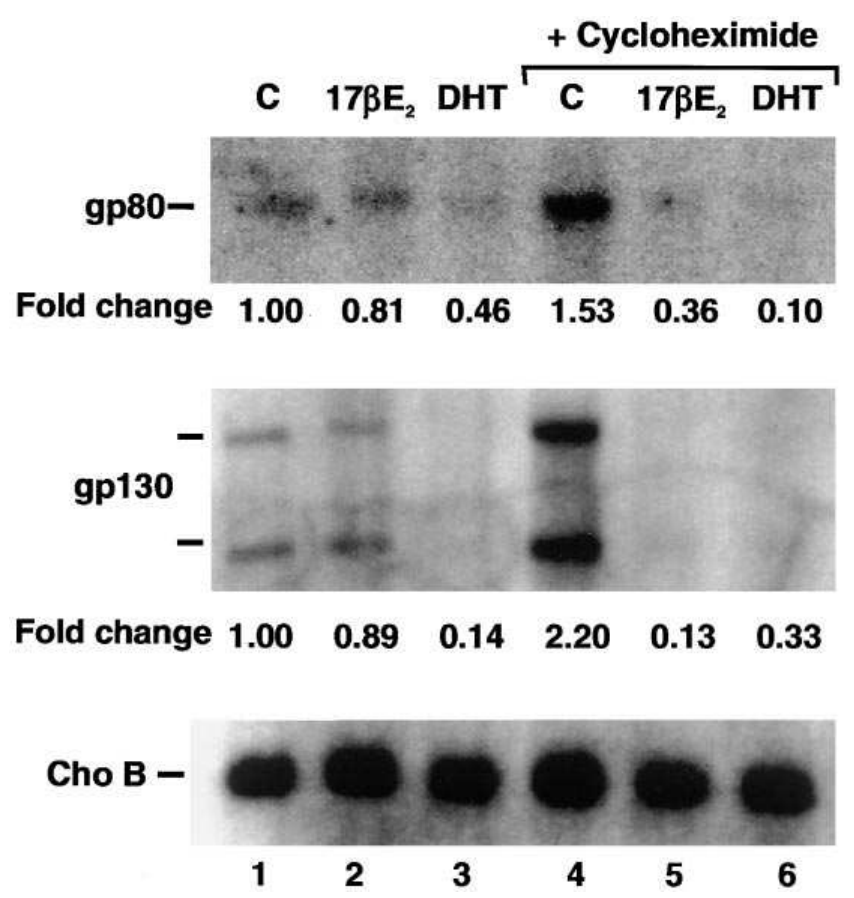

Figure 2. Effect of cycloheximide on the regulation of gp 80 and gp130 mRNAs by sex steroids. +/+LDA11 murine bone marrowderived stromal cells were cultured for $24 \mathrm{~h}$ without $(C)$ or with $10^{-8} \mathrm{M} 17 \beta$-estradiol $\left(17 \beta \mathrm{E}_{2}\right)$, or $10^{-8} \mathrm{M}$ DHT in the absence or presence of $0.5 \mu \mathrm{M}$ cycloheximide. The steady-state levels of gp80, gp130, and ChoB mRNAs were determined by Northern analysis as described in Fig. $1 A$. Fold change indicates ratios of gp80/ChoB and gp130/ChoB relative to control, designated as 1.0.

determined in Western blots using an anti-human gp130 polyclonal antibody that cross-reacts with the murine gp130 protein (Fig. $1 \mathrm{~B}$ ). A protein band corresponding to $\sim 145 \mathrm{kD}$ was detected by the gp130 antibody. An identically migrating band was observed in an anti-gp130 immunoprecipitate from a cellular lysate of control cells. As found here, gp130 exhibits a migration profile corresponding to a $145-\mathrm{kD}$ protein (41). Compared with cultures maintained in the absence of sex steroids, +/+LDA.11 cells treated with either $\mathrm{E}_{2}$ or DHT exhibited lower abundance for this protein. Sex steroids had no effect on the levels of $\beta$-actin. Because an anti-murine gp80 antibody suitable for Western blot analysis was not available to us, we were unable to perform similar experiments for gp80.

In the experiment depicted in Fig. 2, +/+LDA.11 cells were treated with $\mathrm{E}_{2}$, DHT, or vehicle either in the absence (lanes 1, 2 , and 3 ) or in the presence (lanes 4,5 , and 6 ) of $0.5 \mu \mathrm{M}$ cycloheximide. The abundance of both gp80 and gp130 mRNAs was increased in cells treated with cycloheximide, most likely due to increased mRNA stability. $\mathrm{E}_{2}$ and DHT decreased the abundance of the gp 80 and gp130 transcripts in the absence of cycloheximide as well as in its presence, indicating that their effects are independent of new protein synthesis.

Using MC3T3-E1 cells, which, unlike +/+LDA.11 cells, express receptors for PTH (42), we found that as opposed to the inhibitory effect of sex steroids, PTH $(10 \mathrm{nM})$ increased the abundance of the gp130 mRNA by over fourfold (Fig. $3 A$ ). The stimulatory effect of PTH on the gp130 mRNA was reproduced in primary cultures of murine bone marrow cells, and it was also observed in human osteoblast-like osteosarcoma SaOs- 2 cells using flow cytometric analysis of cells stained with an anti-human gp130 antibody (data not shown). DHT, but not $\mathrm{E}_{2}$, decreased the nonstimulated gp130 mRNA in MC3T3E1 cells, as it did in +/+LDA11 cells. Both steroids, however, inhibited the PTH-stimulated expression of this gene. IL-11 and leukemia inhibitory factor (LIF) also stimulated the abundance of the gp130 mRNA in MC3T3-E1 cells (Fig. 3 B). In this experiment, $\mathrm{E}_{2}$ did decrease basal levels of gp130 mRNA. When the cells were treated with both IL-11 and $E_{2}$ or LIF and $E_{2}$, the stimulatory effect of the cytokines was attenuated by $E_{2}$. As in the case of $+/+$ LDA.11 cells, $E_{2}$ decreased both gp130 transcripts.

The relevance of the in vitro evidence, indicating that sex steroids inhibit expression of gp80 and gp130 in cells of the stromal/osteoblastic lineage to the in vivo situation in sex steroid-deficient states, was determined by investigating whether loss of estrogen increases the abundance of the gp80 and gp130 mRNAs in murine bone marrow. Northern blot analysis proved insensitive for this purpose, as we found that the abundance of all these three messages was extremely low in freshly isolated bone marrow cells from either sham or OVX animals. Indeed, the gp130 mRNA was barely detectable, even with as much as $10 \mu \mathrm{g}$ of poly $\mathrm{A}^{+} \mathrm{RNA}$, whereas gp 80 or IL- 6 mRNAs were undetectable. When comparing the expression of these mRNAs in freshly isolated bone marrow cells from sham and OVX mice using RT-PCR, we did not consistently detect differences
A
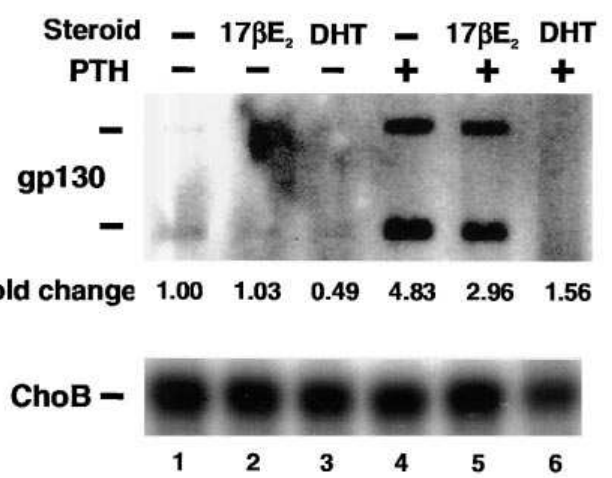

B
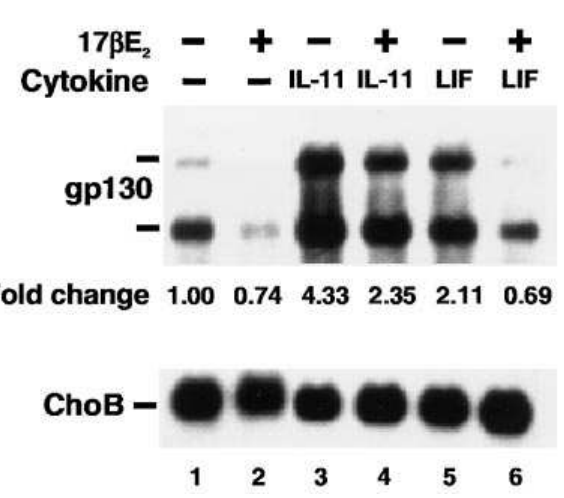

Figure 3. Sex steroids inhibit PTH-, LIF-, and IL-11-stimulated expression of gp130 mRNA in MC3T3-E1 murine osteoblastic cells. MC3T3-E1 osteoblastic cells were cultured for $24 \mathrm{~h}$ in the absence or in the presence of $10 \mathrm{nM} \mathrm{PTH}(A)$ or $10 \mathrm{ng} / \mathrm{ml}$ IL-11, or LIF $(B)$, alone or in combination with $10^{-8} \mathrm{M} 17 \beta$-estradiol $\left(17 \beta \mathrm{E}_{2}\right)$, or $10^{-8} \mathrm{M}$ DHT. The steady-state levels of gp130 and ChoB mRNAs were determined. The ratios of gp130/Cho B were calculated, and are expressed as fold changes relative to control, designated as 1.0. 
A.

$\begin{array}{llllllllllll}1 & 2 & 3 & 4 & 5 & 6 & 7 & 8 & 9 & 10 & 11\end{array}$

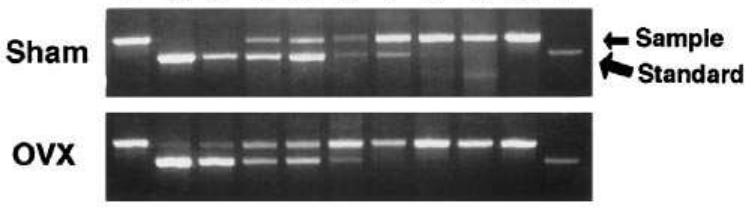

C.

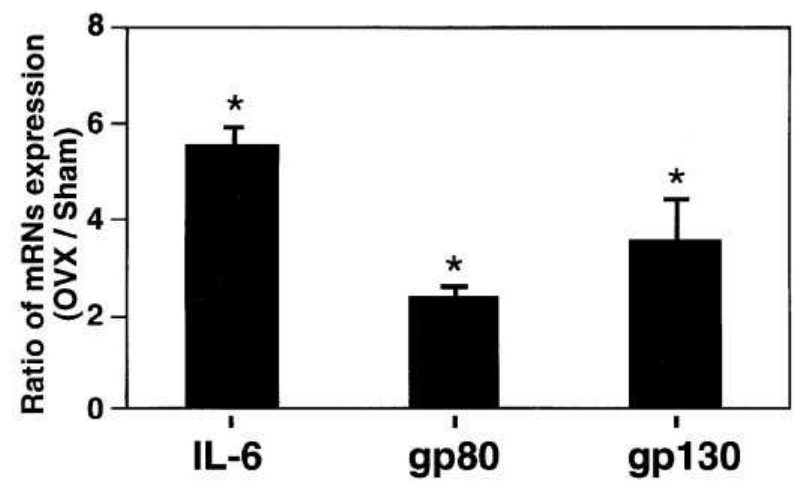

D.
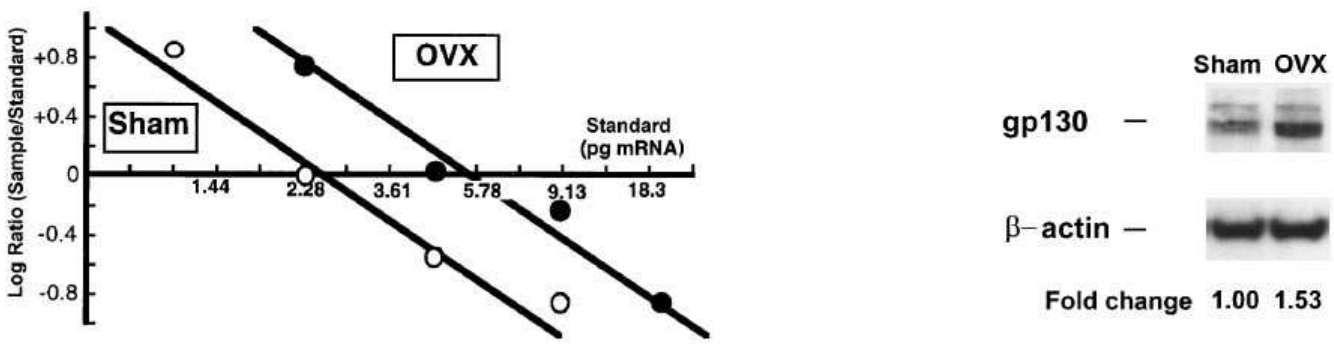

Figure 4. Increased expression of IL-6, gp 80 , and gp130 mRNA in ex vivo bone marrow cultures from ovariectomized mice as determined by competitive RT-PCR. Bone marrow cells from 60-d-old sham-operated (Sham) or OVX mice were cultured for $7 \mathrm{~d}$ in the presence of $10^{-8} \mathrm{M}$ $1,25(\mathrm{OH})_{2} \mathrm{D}_{3}$. Total RNA was obtained, and competitive RT-PCR was performed as described in Methods. PCR products were analyzed by electrophoresis, and bands were quantified by image analyzer. Gel patterns of a representative experiment for gp $80 \mathrm{mRNA}$ obtained from bone marrow cultures of sham and OVX mice are shown in $A$. Lanes 1 and 11 contain sample alone and standard alone, respectively. Lanes $2-10$ show PCR products from the mixtures of constant amounts $(1 \mu \mathrm{g})$ of sample RNA and decreasing amounts (twofold serial dilutions to the right) of internal standard. Band intensities (arbitrary units) in lanes 4-7 for sample/standard from the sham-operated mice were 402/2258, 806/2855, 304/ 366 , and 319/458. Band intensities for lanes 3-6 for ovariectomized mice were 525/4246, 1184/1346, 1607/1702, and 3128/555. The logarithm of the ratio of sample to standard was plotted versus the amounts of internal standard (pg mRNA in log scale). ( $B$ ) Ratio 0 represents concentration of gp80 mRNA in the samples. (C) IL-6, gp80, and gp130 mRNA expression in bone marrow cultures from sham and OVX were analyzed by competitive RT-PCR. Bars depict the means (and vertical lines the standard error) of the ratios $(\mathrm{OVX} / \mathrm{sham})$ from three independent experiments. Data were analyzed by one-way ANOVA. ${ }^{*} P<0.05$ versus sham, by Bonferroni's. The cultures used to detect IL- 6 mRNA expression were stimulated with $0.3 \mathrm{nM}$ hIL-1 and $1 \mathrm{nM} \mathrm{mTNF} \alpha$ for $3 \mathrm{~h}$ before extraction of total RNA. $(D)$ Expression of gp130 protein in bone marrow cells from sham-operated and ovariectomized mice, cultured for $1 \mathrm{wk}$ in the presence of $10^{-8} \mathrm{M} 1,25(\mathrm{OH})_{2} \mathrm{D}_{3}$, was detected by immunoblot analysis. $80 \mu \mathrm{g}$ of total protein were resolved in a $6 \%$ polyacrylamide/SDS gel as described in the Methods section. The blot was probed with an antihuman gp130 polyclonal antibody and an anti- $\beta$-actin monoclonal antibody.

in expression. In an attempt to obtain more consistent results and to overcome the difficulties imposed by the low expression of the mRNAs of interest in the freshly isolated cells, we analyzed the expression of IL-6, gp80, and gp130 in ex vivo cultures.

Fig. $4 A$ illustrates typical gels of the PCR assay for gp80 mRNA in bone marrow cultures from sham and OVX mice. The ratio between PCR products from sample mRNA and internal cRNA was calculated and plotted versus the concentration of the internal standards (Fig. 4 B). gp80 expression in bone marrow cultures from OVX mice was increased as indicated by the shift of the regression line to the right. Similar findings were obtained when we performed competitive RTPCR analysis for gp130 and IL-6 mRNA expression in bone marrow cells from sham and OVX animals. These findings were reproduced in three separate experiments. The mean in- crease in the expression of IL-6, gp80, and gp130 after ovariectomy in the three experiments, was 5.4 $\pm 0.5-, 2.2 \pm 0.1-$, and $3.4 \pm 1.1$-fold, respectively (Fig. $4 C$ ). There was no difference in the control GAPDH mRNA in these experiments. In addition, we were unable to find differences in the abundance of IL- $1 \alpha$, IL-1 $\beta$, and TNF $\alpha$ mRNAs between OVX and sham animals in these experiments (data not shown). The lack of differences between OVX and sham control mice in the IL-1 $\alpha$ expression in the bone marrow is in agreement with the report of Miyaura et al. (22). An increase in gp130 expression in ex vivo bone marrow cultures from OVX mice was documented also at the protein level, using Western blot analysis (Fig. $4 \mathrm{D}$ ).

The results of the competitive RT-PCR indicating an increase in the expression of gp 80 , gp130, and IL-6, could be due to an increase in the number of cells that produced these mRNAs. Therefore, to establish directly that the changes we 
A

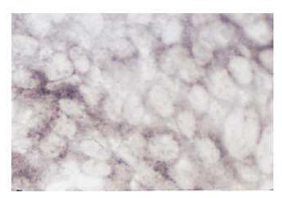

-DNase + RNase

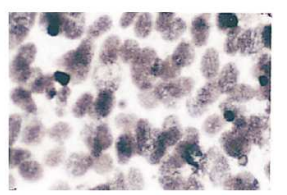

+ DNase + RNase

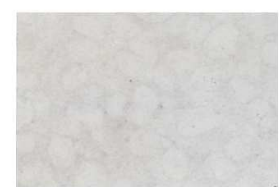

B

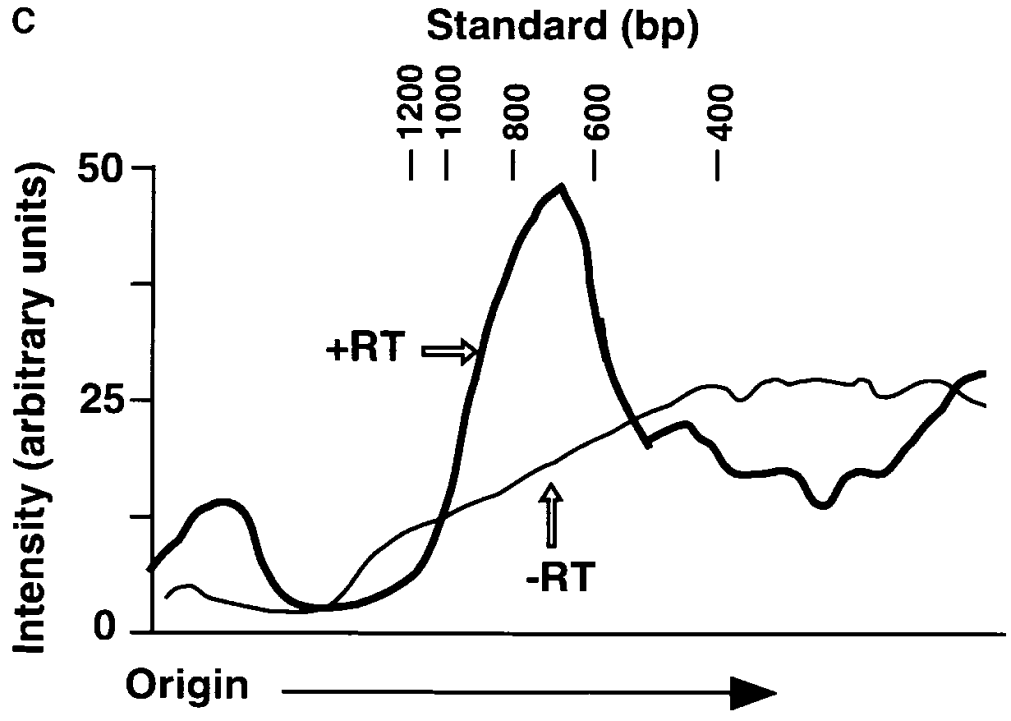

Figure 5. Validation of in situ RT-PCR. (A) 2107 cells cultured on coverslips in multiwell dishes were fixed with $4 \%$ paraformaldehyde and treated with DNase and/or RNase for $3 \mathrm{~h}$ to eliminate genomic DNA and/or mRNA. Subsequently, samples were subjected to RT-PCR using specific primers for murine GAPDH and digoxigenin-labeled dUTP. Incorporated digoxigenin was detected by AP-conjugated antidigoxigenin antibody and visualized with NBT/BCIP. (B) 2107 cells, cultured and fixed as in $A$, were treated with DNAse for $3 \mathrm{~h}$ and reverse transcribed. Subsequently, 0, 10, 20, 30, 40, and 50 PCR cycles using specific primers for murine gp80 cDNA sequence were performed in triplicate. PCR products were detected as in $A$. The color intensity (arbitrary units) in 300 cells in randomly selected fields was measured by video image analyzer, and the average color intensity \pm standard error was plotted versus the number of PCR cycles. Representative photomicrographs are shown at $200 \times$. (C) 2107 cells were cultured and subjected to in situ RT-PCR as in $A$, except that gp130 primers were used, and $\left[{ }^{32} \mathrm{P}\right] \mathrm{dCTP}$ was included in the amplification reaction instead of digoxigenin-labeled dUTP The figure shows the radioactivity distribution of the ${ }^{32} \mathrm{P}$-labeled PCR product obtained by PhosphorImager scanning of the membrane containing resolved products. In situ RT-PCR was performed in the absence $(-R T)$ or presence $(+R T)$ of reverse transcriptase. saw in the ex vivo cultures were indeed due to removal of the inhibitory effects of sex steroids on these genes, we proceeded to investigate whether there was an increase in the expression of these transcripts on a per cell basis. For this purpose, we developed and used in situ RT-PCR, which allowed us to analyze expression of these RNAs in individual cells.

To establish the validity of the in situ RT-PCR method, we examined the expression of the mRNA of a housekeeping gene, GAPDH, under different experimental conditions using the murine osteoblastic cell line 2107 (Fig. 5 A). Confluent cultures of 2107 cells, when treated with DNase (but not RNase) for $3 \mathrm{~h}$, exhibited cytosolic staining but complete lack of staining in the nucleus. On the other hand, when the cells were treated with RNase (but not DNase) for $3 \mathrm{~h}$, only nuclear staining, evidently derived from genomic DNA, was observed. Treatment of the cells with both nucleases completely prevented staining. Based on these findings, in all subsequent experiments bone marrow cells were treated with DNase for $3 \mathrm{~h}$ after 

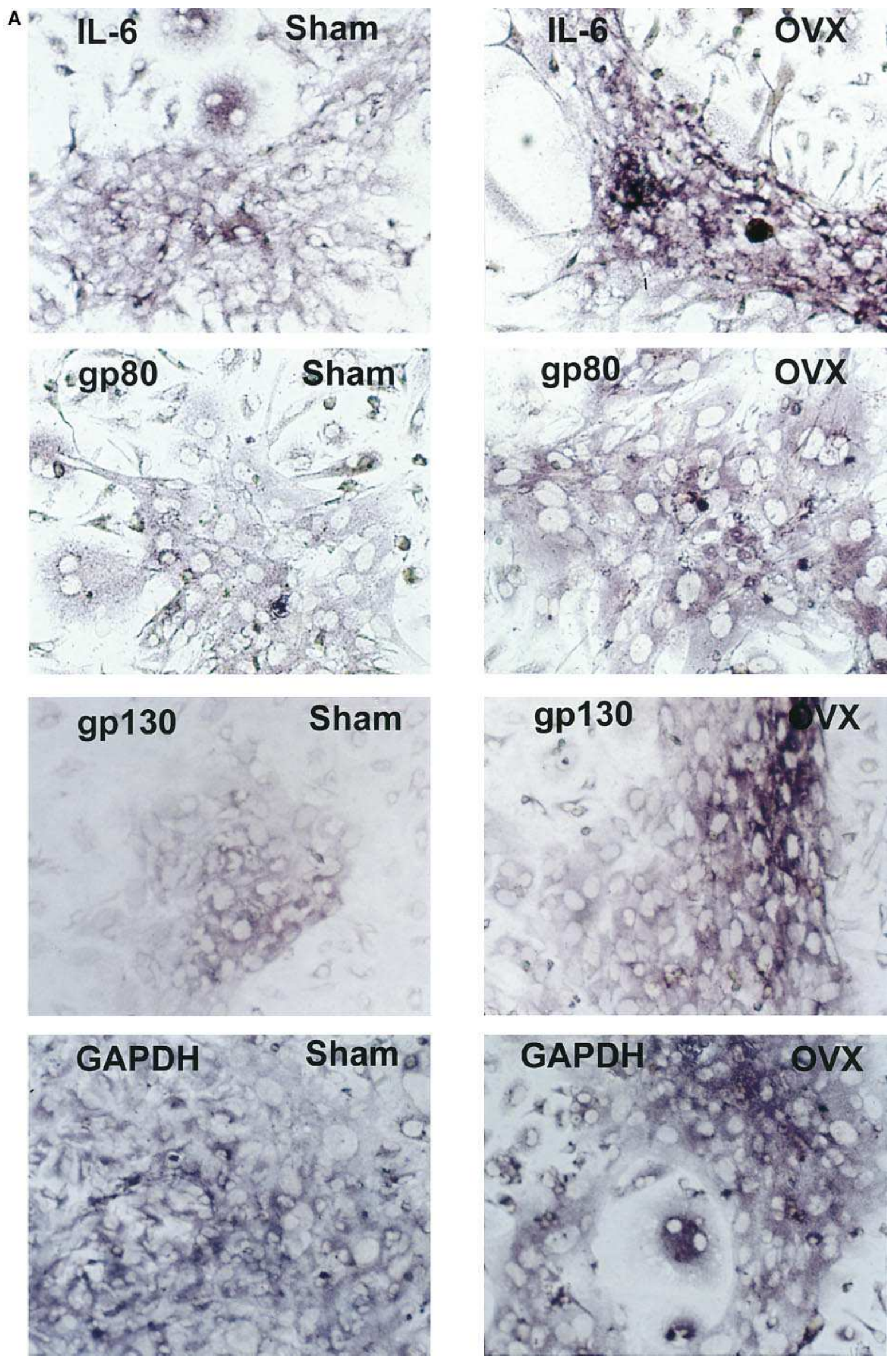

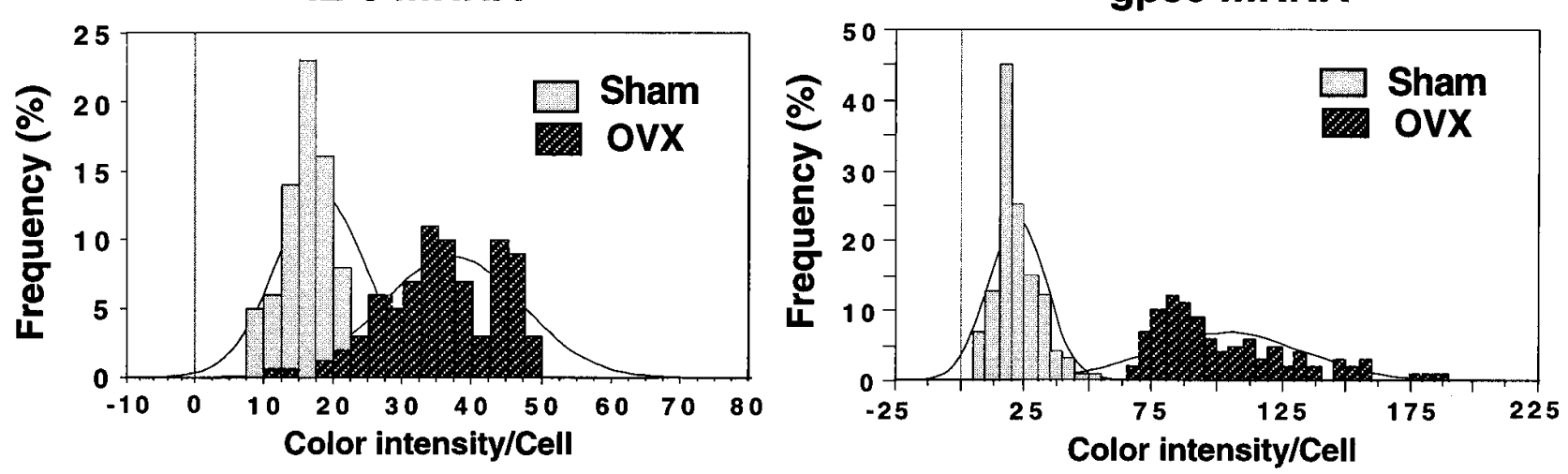

gp130 mRNA
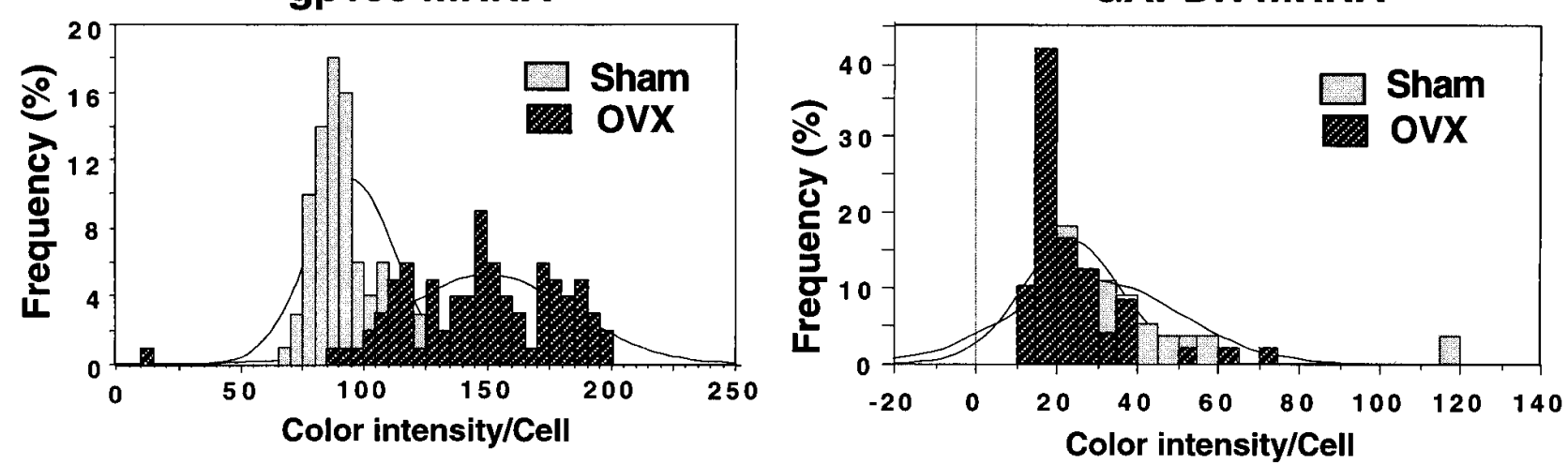

Figure 6. Increased expression of IL-6, gp80, and gp130 mRNA in ex vivo bone marrow cultures from ovariectomized mice as determined by in situ RT-PCR. Bone marrow cells from 60-d-old sham-operated (Sham) or OVX mice were cultured for $7 \mathrm{~d}$ in the presence of $10^{-8} \mathrm{M}$ $1,25(\mathrm{OH})_{2} \mathrm{D}_{3}$. To detect IL- $6 \mathrm{mRNA}$ expression, bone marrow cells were stimulated with $0.3 \mathrm{nM} \mathrm{hIL}-1$ and $1 \mathrm{nM} \mathrm{mTNF} \alpha$ for $3 \mathrm{~h}$ before fixation. Fixation, DNase treatment, and RT-PCR were performed as in Fig. 5. Photomicrographs $(340 \times)$ of a representative experiment are shown in $A$. Color intensity was quantified by image analysis. The percentage of cells expressing each message (frequency) was plotted versus the message level (color intensity/cell), and is shown in $B$.

cell fixation. Furthermore, to establish the optimal number of PCR cycles, confluent cultures of 2107 cells were subjected to $0,10,20,30,40$, or 50 PCR cycles in the in situ PCR 1000 system (Fig. $5 B$ ). As shown in the photomicrographs, color intensity (digoxigenin) of cells stained for gp 80 increased in proportion to the number of PCR cycles. A quantitative measure of this observation was established by video image analysis, where the frequency (percentage) of cells staining positive for the gp80 mRNA was plotted against color intensity in arbitrary units. Average color intensity increased with increasing PCR cycles, and was linear between 10 and 40 cycles. Therefore, in subsequent experiments we routinely used 30 PCR cycles for detection of all three mRNAs of interest. To establish the specificity of in situ RT-PCR, ${ }^{32} \mathrm{P}$-labeled dCTP was included in the amplification reaction, and the size distribution of the products of the reaction was subsequently determined by extraction of the DNA from the coverslips, fractionation in an agarose gel, and quantification using a PhosphorImager (Molecular Dynamics). As seen in Fig. $5 C$, the radioactive DNA extracted from cells amplified with the gp130 primers had the size of the expected gp130 PCR product (687 bp).

By means of the in situ RT-PCR method, we detected a significant difference in the expression of the IL-6, gp80, and gp130 mRNAs between ex vivo bone marrow cell cultures maintained in the presence of $1,25(\mathrm{OH})_{2} \mathrm{D}_{3}$ from OVX when compared with sham-operated animals (Fig. 6). Ovariectomy had no effect on the expression of the GAPDH mRNA, used as a negative control in these experiments. Representative photomicrographs of ex vivo bone marrow cultures from sham or OVX mice are depicted in Fig. $6 \mathrm{~A}$. To quantify the changes in mRNA abundance, color intensity (in arbitrary units) per cell was determined by video imaging of each one of at least 300 mononuclear cells in randomly selected fields, and was plotted against the percentage of cells exhibiting a particular color intensity (Fig. $6 \mathrm{~B}$ ). As can be seen in the photomicrographs, bone marrow cultures from OVX mice exhibited more intense staining for gp80, gp130, and IL-6. This increase was clearly reflected by an increase in the frequency of cells containing higher levels of mRNA as evidenced by the shift of the frequency histograms to the right. Similar results were obtained in four different experiments. The mean increase (and standard error of the mean) in the expression of IL-6, gp80, and gp130 after ovariectomy in these four experiments was $1.63 \pm 0.2-, 3.4 \pm 0.6-$, and 1.8 \pm 0.2 -fold, respectively. GAPDH mRNA abundance was indistinguishable between sham and OVX mice. A quantitative analysis of the changes of the abundance of gp80, gp130, and IL-6 mRNA was also performed in multinucleated cells. Because multinucleated cells were far 
more scarce than were mononucleated cells, we videoimaged 50 multinucleated cells in randomly selected fields in these experiments. As in the case of the mononucleated cell analysis shown in Fig. 6, in two separate experiments we observed an increase in the expression of all three mRNAs after ovariectomy in mono- as well as in multinucleated cells. The mean increase in OVX over sham in the two experiments was 1.5, 4.0, and 1.7 for IL-6, gp80, and gp130, respectively. In contrast to the results of the experiments presented in Figs. 5 and 6 in which we analyzed cultures maintained in the presence of $1,25(\mathrm{OH})_{2} \mathrm{D}_{3}$, in experiments with cultures maintained without $1,25(\mathrm{OH})_{2} \mathrm{D}_{3}$, we were unable to detect differences between OVX and sham-operated animals in any of the three mRNAs by competitive RT-PCR or in situ RT-PCR.

\section{Discussion}

The results of these studies demonstrate that estrogen and androgen decreased in vitro the expression of both gp80 and gp130 in cells of the bone marrow stromal/osteoblastic lineage. These effects did not require new protein synthesis. In contrast to sex steroids, PTH and the IL- 6 type cytokines IL-11 and LIF stimulated the expression of gp130; the effects of these agents were opposed by sex steroids. Measurement of cytokines and their soluble receptors in the serum may or may not reflect changes limited to small cell subpopulations in the marrow/ bone microenvironment, nor do they reveal the cellular source of these agents. Therefore, to establish directly the relevance of the evidence for the suppressive effects of sex steroids on gp80 and gp130 to the in vivo situation and specifically the state of estrogen deficiency, we developed an RT-PCR method to search for in situ changes in gp80 and gp130 mRNA expression. Consistent with the in vitro data, we found that ovariectomy in mice caused an increase in the expression of gp80, gp130, and IL-6 mRNAs in ex vivo bone marrow cell cultures.

The demonstration of increased expression of a gene after loss of sex steroids could be either a direct consequence of the removal of an inhibitory effect on the gene, or result from an increase in the number of cells that express the gene. The demonstration of an inhibitory effect in vitro, taken together with the results of the ex vivo experiments and, in particular, the demonstration of the increases of the transcripts of interest by in situ RT-PCR on a per cell basis, strongly suggest that the increases on the expression of the three genes described here are indeed a direct consequence of the removal of inhibitory effects of sex steroids on the expression of IL-6, gp80, and gp130.

As in the case of the previous demonstration of increased osteoclastogenesis and IL-6 production after loss of sex steroids $(2,3,21)$, in this report increases in the expression of gp80, gp130, and IL-6 in OVX animals were demonstrated in ex vivo cultures maintained in the presence of the potent prodifferentiation agent $1,25(\mathrm{OH})_{2} \mathrm{D}_{3}$. The cells isolated from bone marrow aspirates are composed predominantly of hematopoietic and mesenchymal cell precursors. We believe that culturing these preparations in the presence of $1,25(\mathrm{OH})_{2} \mathrm{D}_{3}$ leads to enrichment of the subpopulation that is the in vivo target of the suppressive effect of sex steroids on IL-6, gp80, and gp130. This contention is in line with the well-established evidence that $1,25(\mathrm{OH})_{2} \mathrm{D}_{3}$ stimulates osteoclastogenesis by promoting both differentiation of mesenchymal progenitors capable of supporting osteoclast differentiation as well as the differentia- tion of hematopoietic osteoclast precursors $(43,44)$. Hence, the presence of $1,25(\mathrm{OH})_{2} \mathrm{D}_{3}$ in the in vitro cultures serves to simulate in vivo situation. Similarly, the requirement of addition of IL-1 and TNF to detect differences in IL-6 expression may be due to removal of these cells from their microenvironmental milieu, which includes paracrine signals that stimulate IL-6 expression such as IL-1, TNF, other IL-6-type cytokines, TGF $\beta$, and PDGF, as well as endocrine signals such as PTH and thyroxin.

In agreement with the results of these studies in mice, results of clinical studies indicate that the ligand-binding subunit of the IL-6 receptor is upregulated after loss of estrogen in humans as well. Thus, Girasole et al. (45) have studied, over $12 \mathrm{mo}$, women who had hysterectomy alone, ovariectomy, and ovariectomy with transdermal estrogen replacement. They observed that the expected rise in markers of bone formation and bone resorption were accompanied at the same time points with increases in soluble IL-6 receptor levels by 35\%, and a smaller increase, $\sim 20 \%$, in serum IL- 6 levels. The increased serum soluble IL-6 receptor levels induced by ovariectomy in women could be reversed by estrogen replacement. Similarly, Chen et al. investigated 151 healthy women in different menstruational status and found that soluble IL-6 receptor levels were significantly increased in postmenopausal women when compared with both premenopausal or perimenopausal women (46).

It is now well accepted that PTH and PTHrP stimulate production of IL- $6(42,47,48)$, and that IL-6 is the mediator of the bone resorbing effects of PTH (49). In this report, we observed that as opposed to estrogen (which inhibits the expression of gp130), PTH stimulates the expression of this gene. Although we were unable to determine whether PTH stimulates expression of gp80, as MC3T3-E1 cells do not express detectable levels of gp80, there is evidence strongly favoring this possibility: besides IL-6, the circulating levels of the soluble IL-6 receptor are increased in patients with primary and secondary hyperparathyroidism $(5,6)$. Moreover, a PTH-induced upregulation of gp80 could explain the observations that PTHrP administered together with IL- 6 causes development of hypercalcemia and bone resorption in mice, whereas administration of IL-6 by itself had no effect (33). In these studies, the stimulating effect of PTH on gp130 was attenuated by $E_{2}$ in vitro. Whether or not these opposing effects are of relevance to the in vivo situation, and in particular the well-known antagonism between PTH and estrogen on bone resorption, will require additional work (50).

In studies not shown here, we have combined in situ RTPCR analysis with histostaining for either tartrate-resistant acid phosphatase (TRAPase) or alkaline phosphatase (AP). The former enzyme is a specific and fairly reliable phenotypic marker for osteoclasts, especially when combined with multinucleation. Cells of the stromal osteoblastic lineage in the bone marrow express AP, however, the validity of this enzyme for identification of cells belonging to the stromal/osteoblastic lineage in the bone marrow is limited, as several other cells of the bone marrow such as leukocytes and adipocytes, also express AP. We have obtained evidence that all three messages, IL-6, gp80, and gp130, are expressed in both TRAPase-positive and AP-positive cells of the bone marrow. Based on these observations and the combination of the results from our in vitro studies with cell lines and ex vivo bone marrow cultures (including the morphologic features and the ploidy of the 
cells), we tentatively conclude that the cells expressing increased levels of IL-6, gp80, and gp130 mRNA after ovariectomy, are bone marrow stromal/osteoblastic cells, macrophages, osteoclastic cells, and progenitors of all of these three cell types, with osteoclastic cells representing $<1 \%$ of the total.

The biologic significance of the inhibitory effects of sex steroids on gp130, and the upregulation of gp130 expression in the bone marrow after estrogen loss is, at this stage, only a matter of conjecture. Nonetheless, we have reported elsewhere that besides PTH, 1,25(OH $)_{2} \mathrm{D}_{3}$ also upregulates gp130 expression in murine bone marrow cell cultures (51). Upregulating effects of PTH and $1,25(\mathrm{OH})_{2} \mathrm{D}_{3}$ on gp130 have been reproduced in studies by Romas et al. (52). Regulation of gp130 expression by systemic hormones and cytokines has been documented in several tissues other than bone. Thus, gp130 expression is increased by IL-6 type cytokines in vivo and in vitro (40, 53-55). In contrast, it has been demonstrated that gp130 expression is decreased by all-trans retinoic acid in myeloma cells (56). Several recent observations support the contention that increasing or decreasing gp130 results in a corresponding increase or decrease of the magnitude of the biological response to IL-6 type cytokines. Hence, in studies reported elsewhere, we have shown that the inhibitory effect of sex steroids on gp130 mRNA and protein is accompanied by a decrease in the amount of activated STAT complexes induced in response to IL-6 type cytokines (57). Moreover, Romas et al. and $\mathrm{Mu}-$ rakami-Mori et al. have found that anti-gp130 antibodies dosedependently inhibit IL-6-type cytokine-induced osteoclast formation and the proliferation of Kaposi's sarcoma cells in vitro, respectively $(52,58)$. Furthermore, the decrease in gp130 induced by all-trans retinoic acid is associated with inhibition of IL-6-dependent human myeloma cell growth (56).

An increase in resorption as well as formation in remodeling bone are well-established features of estrogen deficiency in rodents and humans (1). The former, of course, exceeds the latter, thus causing bone loss. We have recently shown that ovariectomy in mice causes not only upregulation of osteoclastogenesis, but also an increase in the number of osteoblast progenitors in the bone marrow, and that the latter change is temporally associated with increased bone formation as measured by changes in serum osteocalcin (Jilka et al., manuscript submitted for publication). Furthermore, studies by others and us strongly suggest that activation of the gp130 signal transduction pathway by IL-6-type cytokines promotes osteoblast development (59-64). Hence, besides the osteoclastogenic effects of IL-6-type cytokines in the estrogen-deficient state, the same cytokines may also be playing a role in the upregulation of osteoblastogenesis.

In conclusion, the evidence that sex steroid deficiency upregulates IL-6, gp80, and gp130 expression in the bone marrow, that loss of estrogen upregulates not only osteoclastogenesis, but also osteoblastogenesis, and that IL-6-type cytokines may play a role in both processes, supports the hypothesis that estrogen loss increases the production of IL- 6 as well as the responsiveness of osteoclast progenitors, osteoblast progenitors, and stromal/osteoblastic cells that support osteoclastogenesis to IL-6 and related cytokines. Such a scenario could explain both the increased osteoclastogenesis and osteoblastogenesis that follows loss of gonadal function, and thereby the detrimental effect of such loss on the rate of bone remodeling and skeletal homeostasis.

\section{Acknowledgments}

The authors wish to thank Drs. H. Mocharla and G. Passeri for their help in some aspects of this work, and Drs. R.L. Jilka and A.M. Parfitt for critical evaluation of the manuscript.

This work was supported by the National Institutes of Health (PO1AG/AMS13918, RO1AR43003, AR43003 and R29AR43453) and by the Veterans Administration.

\section{References}

1. Manolagas, S.C., and R.L. Jilka. 1995. Bone marrow, cytokines, and bone remodeling. Emerging insights into the pathophysiology of osteoporosis. $N$. Engl. J. Med. 332:305-311.

2. Jilka, R.L., G. Hangoc, G. Girasole, G. Passeri, D.C. Williams, J.S. Abrams, B. Boyce, H. Broxmeyer, and S.C. Manolagas. 1992. Increased osteoclast development after estrogen loss: Mediation by interleukin-6. Science (Wash. DC). 257:88-91.

3. Bellido, T., R.L. Jilka, B.F. Boyce, G. Girasole, H. Broxmeyer, S.A. Dalrymple, R. Murray, and S.C. Manolagas. 1995. Regulation of interleukin-6, osteoclastogenesis and bone mass by androgens. The role of the androgen receptor. J. Clin. Invest. 95:2886-2895.

4. Manolagas, S.C., R.L. Jilka, T. Bellido, C.A. O'Brien, and A.M. Parfitt. 1996. Interleukin-6 type cytokines and their receptors. In Principles of Bone Biology. J.P. Bilezikian, L.G. Raisz, and G.A. Rodan, editors. Academic Press, Inc. San Diego, CA. 701-713.

5. Rusinko, R., J.J. Yin, J. Yee, T. Saad, G.R. Mundy, and T.A. Guise. 1995. Parathyroid hormone (PTH) excess is associated with increased interleukin-6 (IL-6) and soluble IL-6 receptor (sIL-6r) production. J. Bone. Miner. Res. 10: S500(Abstr.).

6. Grey, A., M.A. Mitnick, S. Shapses, A. Ellison, C. Gundberg, and K. Insogna. 1996. Circulating levels of interleukin-6 and tumor necrosis factor-alpha are elevated in primary hyperparathyroidism and correlate with markers of bone resorption - a clinical research center study. J. Clin. Endocrinol. Metab. 81:3450-3454.

7. Roodman, G.D., N. Kurihara, Y. Ohsaki, A. Kukita, D. Hosking, A. Demulder, J.F. Smith, and F.R. Singer. 1992. Interleukin 6: a potential autocrine/paracrine factor in Paget's disease of bone. J. Clin. Invest. 89:46-52.

8. Klein, B., J. Wijdenes, X.-G. Zhang, M. Jourdan, J.-M. Boiron, J. Brochier, J. Liautard, M. Merlin, C. Clement, B. Morel-Fournier, et al. 1991. Murine anti-interleukin-6 monoclonal antibody therapy for a patient with plasma cell leukemia. Blood. 78:1198-1204.

9. De Benedetti, F., M. Massa, P. Pignatti, S. Albani, D. Novick, and A. Martini. 1994. Serum soluble interleukin 6 (IL-6) receptor and IL-6/soluble IL-6 receptor complex in systemic juvenile rheumatoid arthritis. J. Clin. Invest. 93: 2114-2119.

10. Kotake, S., A. Sato, K.J. Kim, N. Takahashi, N. Udagawa, I. Nakamura, A. Yamaguchi, T. Suda, and T. Kashiwazaki. 1996. Interleukin-6 and soluble interleukin-6 receptors in the synovial fluids from rheumatoid arthritis patients are responsible for osteoclast-like cell formation. J. Bone Miner. Res. 11:88-95.

11. Devlin, R.D., H.G. Bone, and G.D. Roodman. 1996. Interleukin-6: a potential mediator of the massive osteolysis in patients with Gorham-Stout disease. J. Clin. Endocrinol. Metab. 81:1893-1897.

12. Salvi, M., G. Girasole, M. Pedrazzoni, M. Passeri, N. Giuliani, R. Minelli, L.E. Braverman, and E. Roti. 1996. Increased serum concentrations of interleukin-6 (IL-6) and soluble IL-6 receptor in patients with Graves disease. J. Clin. Endocrinol. Metab. 81:2976-2979.

13. Lakatos, P., J. Foldes, C. Horvath, L. Kiss, A. Tatrai, I. Takacs, G. Tarjan, and P.H. Stern. 1997. Serum interleukin-6 and bone metabolism in patients with thyroid function disorders. J. Clin. Endocrinol. Metab. 82:78-81.

14. Yamamoto, T., K. Ozono, S. Kasayama, K. Yoh, K. Hiroshima, M. Takagi, S. Matsumoto, T. Michigami, K. Yamaoka, T. Kishimoto, and S. Okada. 1996. Increased IL-6 production by cells isolated from the fibrous bone dysplasia tissues in patients with McCune-Albright syndrome. J. Clin. Invest. 98:30-35.

15. Langub, M.C., N.J. Koszewski, H.V. Turner, M. Monier-Faugere, Z. Geng, and H.H. Malluche. 1996. Bone resorption and mRNA expression of IL-6 and IL-6 receptor in patients with renal osteodystrophy. Kidney Int. 50:515-520.

16. Girasole, G., R.L. Jilka, G. Passeri, S. Boswell, G. Boder, D.C. Williams, and S.C. Manolagas. 1992. 17 $\beta$-estradiol inhibits interleukin-6 production by bone marrow-derived stromal cells and osteoblasts in-vitro: a potential mechanism for the antiosteoporotic effect of estrogens. J. Clin. Invest. 89:883-891.

17. Pottratz, S., T. Bellido, H. Mocharla, D. Crabb, and S.C. Manolagas. 1994. $17 \beta$-estradiol inhibits expression of human interleukin-6 promoterreporter constructs by a receptor-dependent mechanism. J. Clin. Invest. 93:944950.

18. Ray, A., K.E. Prefontaine, and P. Ray. 1994. Down-modulation of Interleukin-6 gene expression by $17 \beta$-estradiol in the absence of high affinity DNA binding by the estrogen receptor. J. Biol. Chem. 269:12940-12946.

19. Stein, B., and M.X. Yang. 1995. Repression of the Interleukin-6 Pro- 
moter by Estrogen Receptor Is Mediated by NF-кB and C/EBPß. Mol. Cell. Biol. 15:4971-4979.

20. Bismar, H., I. Diel, R. Ziegler, and J. Pfeilschifter. 1995. Increased cytokine secretion by human bone marrow cells after menopause or discontinuation of estrogen replacement. J. Clin. Endocrinol. Metab. 80:3351-3355.

21. Passeri, G., G. Girasole, R.L. Jilka, and S.C. Manolagas. 1993. Increased interleukin-6 production by murine bone marrow and bone cells after estrogen withdrawal. Endocrinology. 133:822-828.

22. Miyaura, C., K. Kusano, T. Masuzawa, O. Chaki, Y. Onoe, M. Aoyagi, T. Sasaki, T. Tamura, Y. Koishihara, Y. Ohsugi, and T. Suda. 1995. Endogenous bone-resorbing factors in estrogen deficiency: cooperative effects of IL-1 and IL-6. J. Bone Miner. Res. 10:1365-1373.

23. Glasebrook, A.L., L.L. Short, H.W. Cole, M. Sato, and H.U. Bryant. 1995. Regulation of serum IL-6 by raloxifene in an ovx rat model. Bone. 16: 99S(Abstr.).

24. Zuckerman, S.H., N. Bryan-Poole, G.F. Evans, L. Short, and A.L. Glasebrook. 1995. In vivo modulation of murine serum tumour necrosis factor and interleukin-6 levels during endotoxemia by oestrogen agonists and antagonists. Immunology. 86:18-24.

25. McKane, W.R., S. Khosla, J.M. Peterson, K. Egan, and B.L. Riggs. 1994. Circulating levels of cytokines that modulate bone resorption: effects of age and menopause in women. J. Bone Miner. Res. 9:1313-1318.

26. Kassem, M., S. Khosla, T.C. Spelsberg, and L. Riggs. 1996. Cytokine production in the bone marrow microenvironment: failure to demonstrate estrogen regulation in early postmenopausal women. J. Clin. Endocrinol. Metab. 81:513-518.

27. Poli, V., R. Balena, E. Fattori, A. Markatos, A. Yamamoto, H. Tanaka, G. Ciliberto, G.A. Rodan, and F. Costantini. 1994. Interleukin-6 deficient mice are protected from bone loss caused by estrogen depletion. EMBO J. 13:11891196.

28. Stahl, N., and G.D. Yancopoulos. 1993. The alphas, betas, and kinases of cytokine receptor complexes. Cell. 74:1-4.

29. Kishimoto, T., T. Taga, and S. Akira. 1994. Cytokine signal transduction. Cell. 76:253-262.

30. Zhong, Z., Z. Wen, and J.E.J. Darnell. 1994. Stat3: a STAT family member activated by tyrosine phosphorylation in response to epidermal growth factor and interleukin-6. Science (Wash. DC). 264:95-98.

31. Ihle, J.N. 1996. STATs: signal transducers and activators of transcription. Cell. 84:331-334.

32. Girasole, G., G. Passeri, R.L. Jilka, and S.C. Manolagas. 1994. Interleukin-11: a new cytokine critical for osteoclast development. J. Clin. Invest. 93: $1516-1524$.

33. De La Mata, J., H.L. Uy, T.A. Guise, B. Story, B.F. Boyce, G.R. Mundy, and G.D. Roodman. 1995. Interleukin-6 enhances hypercalcemia and bone resorption mediated by parathyroid hormone-related protein in vivo. J. Clin. Invest. 95:2846-2852.

34. Bellido, T., N. Stahl, T.J. Farruggella, V. Borba, G.D. Yancopoulos, and S. Manolagas. 1996. Detection of receptors for interleukin-6, interleukin-11, leukemia inhibitory factor, oncostatin $\mathrm{M}$, and ciliary neurotrophic factor in bone marrow stromal/osteoblastic cells. J. Clin. Invest. 97:431-437.

35. Tamura, T., N. Udagawa, N. Takahashi, C. Miyaura, S. Tanaka, Y. Yamada, Y. Koishihara, Y. Ohsugi, K. Kumaki, T. Taga, et al. 1993. Soluble interleukin-6 receptor triggers osteoclast formation by interleukin 6. Proc. Natl. Acad. Sci. USA. 90:11924-11928.

36. Sudo, H., H.A. Kodama, Y. Amagai, S. Yamamoto, and S. Kasai. 1983. In vitro differentiation and calcification in a new clonal osteogenic cell line derived from newborn mouse calvaria. J. Cell Biol. 96:191-198.

37. Heremans, H., A. Billiau, J.J. Cassiman, J.C. Mulier, and P. Desomer. 1978. In vitro cultivation of human tissues II. Morphology and virological characteristics of three cell lines. Oncology (Basel). 35:246-252.

38. Fogh, J., W.C. Wright, and J.D. Loveless. 1977. Absence of HeLa cell contamination in 169 cell lines derived from human tumors. J. Natl. Cancer Inst. 58:209-214.

39. Mocharla, H., A.W. Butch, A.A. Pappas, J.T. Flick, R.S. Weinstein, P. DeTogni, R.L. Jilka, P.K. Roberson, A.M. Parfitt, and S.C. Manolagas. 1997. Quantification of vitamin D receptor mRNA by competitive polymerase chain reaction in PBMC: lack of correspondence with common allelic variants. $J$. Bone Miner. Res. 12:726-733.

40. Saito, M., K. Yoshida, M. Hibi, T. Taga, and T. Kishimoto. 1992. Molecular cloning of a murine IL-6 receptor-associated signal transducer, gp130, and its regulated expression in vivo. J. Immunol. 148:4066-4071.

41. Stahl, N., S. Davis, V. Wong, T. Taga, T. Kishimoto, N.Y. Ip, and G.D. Yancopoulos. 1993. Cross-linking identifies leukemia inhibitory factor-binding protein as a ciliary neurotrophic factor receptor component. J. Biol. Chem. 268: $7628-7631$

42. Sakagami, Y., G. Girasole, X. Yu, H.S. Boswell, and S.C. Manolagas. 1993. Stimulation of interleukin-6 production by either calcitonin gene-related peptide or parathyroid hormone in two phenotypically distinct bone marrowderived murine stromal cell lines. J. Bone Miner. Res. 8:811-816.

43. Owen, T.A., M.S. Aronow, L.M. Barone, B. Bettencourt, G.S. Stein, and J.B. Lian. 1991. Pleiotropic effects of vitamin D on osteoblast gene expression are related to the proliferative and differentiated state of the bone cell phenotype: dependency upon basal levels of gene expression, duration of exposure and bone matrix competency in normal rat osteoblast cultures. Endocrinology. 128:1496-1504.

44. Suda, T., N. Takahashi, and T.J. Martin. 1995. Modulation of osteoclast differentiation: update 1995. Endocr. Rev. 4:266-270.

45. Girasole, G., M. Pedrazzoni, N. Giuliani, G. Passeri, and M. Passeri. 1995. Increased serum soluble interleukin-6 receptors levels are induced by ovariectomy, prevented by estrogen replacement and reversed by alendronate administration. J. Bone Miner. Res. 10:S160(Abstr.).

46. Chen, J.T., N. Maruo, T. Kato, E. Hasumi, E. Ogata, M. Shiraki, and I. Morita. 1996. Serum level of soluble interleukin-6 receptor, not interleukin-6, is correlated with bone resorption markers and lumbar bone mineral density after menopause. J. Bone Miner. Res. 10:S347(Abstr.).

47. Feyen, J.H.M., P. Elford, R.E. Dipadova, and U. Trechsel. 1989. Interleukin- 6 is produced by bone and modulated by parathyroid hormone. J. Bone Miner. Res. 4:633-638.

48. Lowik, C.W.G.M., G. van der Pluijm, H. Bloys, K. Hoekman, O.L.M. Bijvoet, L.A. Aarden, and S.E. Papapoulos. 1989. Parathyroid hormone (PTH) and PTH-like protein (PLP) stimulate interleukin-6 production by osteogenic cells: a possible role of interleukin-6 in osteoclastogenesis. Biochem. Biophys. Res. Commun. 162:1546-1552.

49. Greenfield, E.M., S.M. Shaw, S.A. Gornik, and M.A. Banks. 1995. Adenyl cyclase and interleukin 6 are downstream effectors of parathyroid hormone resulting in stimulation of bone resorption. J. Clin. Invest. 96:1238-1244.

50. Cosman, F., V. Shen, F. Xie, M. Seibel, A. Ratcliffe, and R. Lindsay. 1993. Estrogen protection against bone resorbing effects of parathyroid hormone infusion. Ann. Intern. Med. 118:337-343.

51. Bellido, T., G. Girasole, G. Passeri, R.L. Jilka, and S.C. Manolagas 1994. gp130 mRNA is increased by PTH and cytokines and decreased by sex steroids in stromal/osteoblastic cells. J. Bone Miner. Res. 9:S123(Abstr.).

52. Romas, E., N. Udagawa, H. Zhou, T. Tamura, M. Saito, T. Taga, D.J. Hilton, T. Suda, K.W. Ng, and T.J. Martin. 1996. The role of gp130-mediated signals in osteoclast development: regulation of interleukin 11 production by osteoblasts and distribution of its receptor in bone marrow cultures. J. Exp. Med. 183:2581-2591.

53. Schoester, M., P.C. Heinrch, and L. Graeve. 1994. Regulation of interleukin-6 receptor expression by interleukin-6 in human monocytes-a re-examination. FEBS Lett. 343:131-134.

54. Snyers, L., and J. Content. 1992. Enhancement of IL-6 receptor $\beta$ chain (gp130) expression by IL-6, IL-1, and TNF in human epithelial cells. Biochem. Biophys. Res. Commun. 185:902-908.

55. Schooltink, H., H. Schmitz-Van de Leur, P.C. Heinrich, and S. RoseJohn. 1992. Up-regulation of the interleukin-6-signal transducing protein (gp130) by interleukin-6 and dexamethasone in HepG2 cells. FEBS Lett. 297: 263-265.

56. Sidell, N., T. Taga, T. Hirano, T. Kishimoto, and A. Saxon. 1991. Retinoic acid-induced growth inhibition of a human myeloma cell line via downregulation of IL-6 receptors. J. Immunol. 146:3809-3814.

57. Lin, S.-C., C.A. O’Brien, and S.C. Manolagas. 1996. Sex steroids decrease and glucocorticoids increase the levels of gp130 protein in bone marrowderived stromal cells: correlation with altered IL-6 induced DNA-binding activity of Stat1 and Stat 3 complexes. J. Bone Miner. Res. 11:S161(Abstr.)

58. Murakami-Mori, K., T. Taga, T. Kishimoto, and S. Nakamura. 1995. AIDS-associated Kaposi's sarcoma (KS) cells express oncostatin M (OM)-specific receptor but not leukemia inhibitory factor/OM receptor or Interleukin-6 receptor. J. Clin. Invest. 96:1319-1327.

59. Metcalf, D., and D.P. Gearing. 1989. Fatal syndrome in mice engrafted with cells producing high levels of the leukemia inhibitory factor. Proc. Natl. Acad. Sci. USA. 86:5948-5952.

60. Takahashi, K., R.L. Jilka, and S.C. Manolagas. 1996. Estrogens alters the responsiveness of osteoblast progenitors to leukemia inhibitory factor (LIF). J. Bone Miner. Res. 11:S129(Abstr.).

61. Taguchi, Y., T. Yamate, H. Mocharla, S.-C. Lin, A. Vertino, P. DeTogni, E. Abe, and S.C. Manolagas. 1996. Interleukin-6 induces osteoblast differentiation in uncommitted embryonic fibroblasts (EF). J. Bone Miner. Res. 11:S101(Abstr.)

62. Ware, C.B., M.C. Horowitz, B.R. Renshaw, J.S. Hunt, D. Liggitt, S.A. Koblar, B.C. Gliniak, H.J. McKenna, T. Papayannopoulou, B. Thoma, et al. 1995. Targeted disruption of the low-affinity leukemia inhibitory factor receptor gene causes placental, skeletal, neural, and metabolic defects and results in perinatal death. Development (Cambridge). 121:1283-1299.

63. Malik, N., H.S. Haugen, B. Modrell, M. Shoyab, and C.H. Clegg. 1995. Developmental abnormalities in mice transgenic for bovine oncostatin M. Mol. Cell. Biol. 15:2349-2358.

64. Bellido, T., V.Z.C. Borba, P.K. Roberson, and S.C. Manolagas. 1997. Activation of the JAK/STAT signal transduction pathway by IL- 6 type cytokines promotes osteoblast differentiation. Endocrinology. 138:3666-3676. 